\title{
UGT2B15 Gene
}

National Cancer Institute

\section{Source}

National Cancer Institute. UGT2B15 Gene. NCI Thesaurus. Code C105420.

This gene is involved in the metabolism of steroids and xenobiotics. 